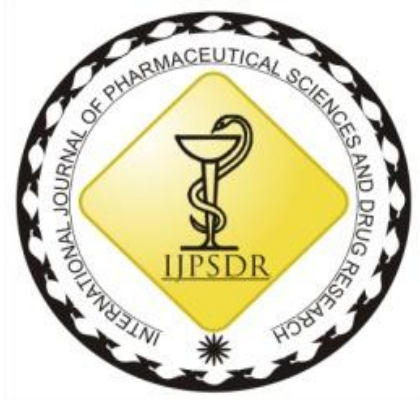

RESEARCH ARTICLE
ISSN: 0975-248X CODEN (USA): IJPSPP $(\mathrm{cc})$ EY-NC-SA

\title{
Essential Oils of Aerial Parts of Anaphalis margaritacea (L.) Benth., Salvia leucantha Cav. and Thymus linearis Benth. From Uttarakhand Himalaya: Chemical Constituents and Antibacterial Activity
}

\author{
B. C. Joshi' ${ }^{1}$ Vinod Kumar ${ }^{2 *}$, Bhuwan Chandra², N. D. Kandpal² \\ ${ }^{1}$ Department of Chemistry, M. B. P. G. College, Haldwani, Nainital, Uttarakhand, India \\ ${ }^{2}$ Department of Chemistry, Kumaun University, S. S. J. Campus, Almora, Uttarakhand, India
}

Copyright (C) 2019 B. C. Joshi et al. This is an open access article distributed under the terms of the Creative Commons AttributionNonCommercial-ShareAlike 4.0 International License which allows others to remix, tweak, and build upon the work non-commercially, as long as the author is credited and the new creations are licensed under the identical terms.

\begin{abstract}
The components present in the essential oils extracted from Anaphalis margaritacea (L.) Benth., Salvia leucantha Cav. and Thymus linearis Benth. were identified by GC and GC/MS analysis. The main compounds present in the oils were aromadendrene $(20.0 \%)$ in S. leucantha, Phellandrene (12.5\%), $\alpha$-thujene $(12.0 \%)$ in A. margaritacea and thymol (50.0\%) in T. linearis. The antibacterial activity of all the three oils against E. coli, P. aeruginosa, S. aureus and $S$. typhi, has been studied. In the antibacterial activity $S$. typhi is the most resistant bacteria to all the tested oils whereas essential oil of T. linearis showed highest antibactericidal activity against $S$. aureus in diffusion method.
\end{abstract}

Keywords: Essential oil, Antibacterial activity, Salvia leucantha, Anaphalis margaritacea, Thymus linearis.

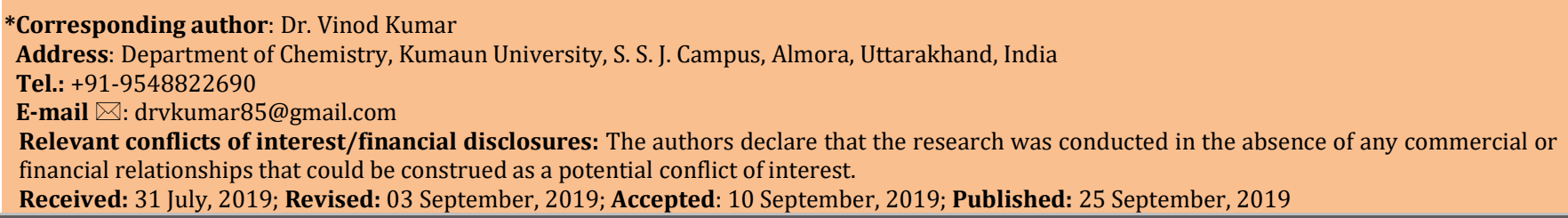

\section{INTRODUCTION}

Phytochemical with biological activities have been used for a wide range of industrial, pharmaceutical and biological utility. In future biopharmaceuticals may create a new field in medicine and pharmaceuticals. The Himalayas have a great wealth of medicinal plants. Medicinal herbs are the main ingredients of local medicines and are thus of vital importance in traditional health-care. The plant species Anaphalis margaritacea, Salvia leucantha and Thymus linearis are rich in terpenoids and reported in medicinal used as herbal product. In some cases herbal remedies provide safe alternative to synthetic drugs. The extracts including volatile constituents of many plants species have shown interesting biological activities leading to researches focused on the characterization of antimicrobial constituents of these plants. [1-3]

The species taken in the study have been used in the treatment of different diseases namely diarrhea, ulcers, antioxidant, antifungal, antiviral and fever [4-13] etc. Various species of genus Salvia have been documented for their antimicrobial, hepatoprotective and bitingdeterrent activity. [14-16] The compound obtained from thyme is known to posses several biological activities such as antibacterial, analgesic, antipyretic, antiparasitic, alleopatic, antiviral, and anti- 
inflammatory. [6-12] The compounds present in the essential oil obtained from A. margaritacea shown good pharmacological properties like antiseptic and sedative. [4-5] The oils extracted from the species Anaphalis, Thymus and Salvia have importance in biological activities. Thus, all the three species can serve as models for phytochemical studies and related biological aspects.

In the present study we have used the part of plant above ground from different climatic conditions as already reported. In order to assess the pharmaceutical importance of the compounds present in the essential oil obtained from the species. The target of the study is to obtain the biological activity of plants namely $A$. margaritacea, $S$. leucantha and $T$. linearis from Uttarakhand Himalaya from different locations for the optimum results. The essential oil obtained from any species with different percentage of constituents can give different activity against any microorganism as already reported for studied. The composition of the compounds may depend upon the climatic conditions of the naturally growing area of plant. It has been possible to predict activity of the compounds present in the essential oil of the plant. Thymol ${ }^{[10-12]}$ which is the marker constituents of $T$. linearis is reported in the literature has been taken for the confirmation of the result in our study along with synthetic antibiotic gentamycin.

\section{MATERIALS AND METHODS}

\section{Plant Collection}

Anaphalis margaritacea from Binsar hill Almora at $29^{\circ} 40^{\prime} 09.55^{\prime \prime} \mathrm{N}$ latitudes and 79०43'13.27"E longitudes, $1843 \mathrm{~m}$ (KU/CHE/ALM-01), Thymus linearis from Hemkund Chamoli at $30^{\circ} 40^{\prime} 42.76^{\prime \prime} \mathrm{N}$ latitudes and 79035'20.45"E longitudes, 2763m (KU/CHE/ALM-02) and Salvia leucantha from Almora at 30 $07^{\prime} 31.69^{\prime \prime} \mathrm{N}$ latitudes and 79050'02.91"E longitudes, $1860 \mathrm{~m}$ (KU/CHE/ALM-03) were collected at the flowering stage in the month of August and September and specified the plant species by Kumaun University, Botany Department.

\section{Chemicals}

Anhydrous $\mathrm{Na}_{2} \mathrm{SO}_{4}$, dimethyl sulphoxide (DMSO) of analytical grade, Merk was used in the study. The media Mueller-Hinton broth (MHB) and MuellerHinton agar (MHA) of Hi-Media, India make was taken in the study of antibacterial activity.

\section{Hydrodistillation of plant materials}

The hydrodistillation of plant material was carried out with Clevenger type apparatus. Each material of 700 gm was extracted for three hours with 1 liter distilled water. The procedure followed for extraction is well established method and reported in literature. [17] The extract was dehydrated with by anhydrous $\mathrm{Na}_{2} \mathrm{SO}_{4}$. The estimation of oils was calculated from $\mathrm{v} / \mathrm{w}$ in percentage. The temperature of the oil was maintained $4^{\circ} \mathrm{C}$ during storage.
The samples were analyzed with the gas chromatography (GC) showed by the instrument Varian vista 6000 having D.B.-5 non polar silica capillary column $60 \mathrm{~m} \times 0.40 \mathrm{~mm}$, film thickness: $0.25 \mu \mathrm{m}$. The $10 \%$ solutions of the oil in $n$-hexane were injected in a volume $0.5 \mu \mathrm{L}$ and the detector was allowed to record the chromatograph at $250^{\circ} \mathrm{C}$. The oven temperature was maintained $40-250^{\circ} \mathrm{C}$ with the rate $3^{\circ} \mathrm{C} / \mathrm{min}$. GC/MS analysis was done by Thermo Quest Trace GC 2000 with a Finnigan MAT Polaris Q ion trap mass spectrometer. During the measurements the volume of injection was capped $0.10 \mu \mathrm{L}$ and split ratio1:40 keeping other parameters constant as used in GC. The MS were taken at $70 \mathrm{eV}$ with a mass range of 40-450 amu.

\section{Compound identification of essential oils}

The compounds of the oil were identified by the values of retention time $(R T)$ and retention index $(R I)$ obtained from GC relative to n-alkanes $\left(C_{8}-C_{23}\right)$ series. The comparison between experimental and standard retention values reported in the MS library search (NIST and WILEY) was also considered. For further identification of mass spectra the values obtained in the spectra were confirmed with the values reported mass spectrum literature data. [18] The percentage of all the compounds was obtained from the experimentally measured value by GC FID without using correction factors.

\section{Determination of antibacterial activity \\ Bacterial strains}

The in vitro biological activity was carried out against bacterial strains namely [Pseudomonas aeruginosa (MTCC No. 424), Escherichia coli (MTCC No. 443), Staphylococcus aureus (MTCC No. 737) and Salmonell typhi (MTCC No. 531)] obtained from Microbiology laboratory, Sushila Tewari Forest Hospital Trust, Haldwani, Nainital, Uttarakhand which were purchased from the Institute of Microbial Technology, Chandigarh. The bacterial culture was maintained at $4^{\circ} \mathrm{C}$ on agar-agar media throughout the work.

\section{Antibacterial activity evaluation}

We have attempted well diffusion method for the evaluation of antibacterial activity of the oils obtained in the study. [19] The solutions of the oils in dimethyl sulphoxide (DMSO) were used for the evaluation process having known concentration. The petri dishes with the dimension $90 \mathrm{~mm}$ were used for the preparation of the media having volume $20 \mathrm{~mL}$ of Mueller-Hinton agar and microbial culture $\left(1 \times 10^{6}\right.$ $\mathrm{CFU} / \mathrm{mL}$ ) spread along the surface of the hole media. The well having capacity $15 \mu \mathrm{L} / \mathrm{mL}$ of sample by cutting it with dimension of $2 \mathrm{~mm}$ borer. The reference standard antibiotic gentamicin was taken as positive control and DMSO as negative control. The diffusion of samples was allowed for three hours at room temperature followed by incubation period 24 hours at $37 \pm 1^{\circ} \mathrm{C}$. Antibacterial activity was observed in $\mathrm{mm}$ dimension of inhibition zone. 
Table 1: Major compounds of essential oil from Asteraceace and Lamiaceae species analysed by GC and GC/MS data.

\begin{tabular}{|c|c|c|c|c|c|}
\hline \multirow{2}{*}{ Major Compoundsa } & \multirow{2}{*}{$\mathbf{R} \mathbf{I}^{\mathbf{b}}$} & \multirow{2}{*}{$\mathbf{R I}^{\mathrm{c}}$} & \multicolumn{3}{|c|}{ Compound \% } \\
\hline & & & A. margaritacea & T. linearis & S. leucantha \\
\hline a-Thujene(2) & 924 & 926 & 12.0 & - & - \\
\hline a-Pinene (3) & 939 & 940 & 10.0 & - & - \\
\hline a-Phellandrene(1) & 1002 & 1005 & 12.5 & - & - \\
\hline Thymol(5) & 1306 & 1302 & - & 50.0 & - \\
\hline$\beta$-Caryophyllene(7) & 1419 & 1421 & - & - & 12.0 \\
\hline Aromadendrene (6) & 1441 & 1439 & - & - & 20.0 \\
\hline Germacrene-D-4-ol(4) & 1574 & 1574 & 8.5 & 6.1 & 8.0 \\
\hline Caryophyllene oxide(8) & 1583 & 1581 & - & - & 5.0 \\
\hline
\end{tabular}

aMS, NIST and WILEY libraries spectra and the literature. ${ }^{\mathrm{b}}$ Literature retention index (RI) on DB-5 column.

${ }^{c}$ Calculated retention index (RI) relative to homologous series of n-alkanes $\left(\mathrm{C}_{8}-\mathrm{C}_{23}\right)$ on D.B.-5 non-polar fused silica capillary column.

Table 2: Antibacterial activity of essential oil from Asteraceace and Lamiaceae species.

\begin{tabular}{ccccc}
\hline \multirow{2}{*}{ Samples } & \multicolumn{4}{c}{$\begin{array}{c}\text { Daimeter of Inhibition Zone (mean } \pm \text { SD) } \mathbf{~ m m}^{\mathbf{a}} \\
\text { Bacterial strains }\end{array}$} \\
\cline { 2 - 5 } & S. typhi & E. coli & S. aureus & P. aeruginosa \\
\hline Essential oils & & & & \\
A. margaritacea & $4.0 \pm 0.3$ & $7.0 \pm 0.2$ & $8.0 \pm 0.1$ & $5.0 \pm 0.2$ \\
$\quad \begin{array}{c}\text { T. linearis } \\
\text { S. leucantha }\end{array}$ & $8.0 \pm 0.1$ & $8.0 \pm 0.2$ & $10.0 \pm 0.2$ & $7.0 \pm 0.2$ \\
$\begin{array}{c}\text { Reference } \\
\text { antibiotic }\end{array}$ & $3.0 \pm 0.1$ & $5.0 \pm 0.1$ & $6.0 \pm 0.1$ & $3.0 \pm 0.1$ \\
Gentamicin & $18.4 \pm 0.2$ & $24.3 \pm 0.1$ & $21.0 \pm 0.2$ & $20.6 \pm 0.2$ \\
\hline
\end{tabular}

anhibition zone diameter includes well diameter
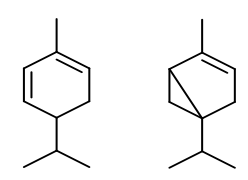

2

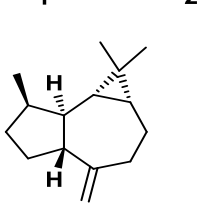

6

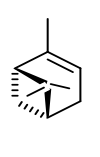

3

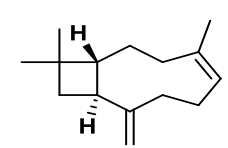

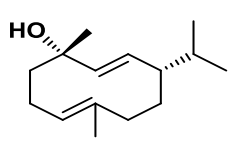

4

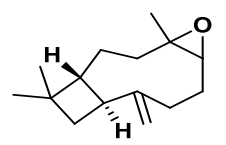

8
Fig. 1: Chemical structure of major compounds.

\section{RESULTS AND DISCUSSION}

The results obtained from the GC and GC/MS analysis for essential oils extracted from different plant are given in Table 1 . The compounds and present in the oils were identified by comparing their retention time (RT) and retention index (RI) with the authenticated reported values. The isolation and characterization of terpenoid constituents obtained from A. margaritacea, $S$. leucantha and $T$. linearis showed that the percentage yield $(\mathrm{v} / \mathrm{w})$ of the oil was $0.1 \%, 0.1 \%$ and $0.2 \%$ respectively. The experimental results are mentioned in the Table 1 along with Fig. 1 . In the study the major constituents obtained from A. margaritacea having aPhellandrene $(12.5 \%)$, a-thujene $(12.0 \%), \quad$ a-pinene $(10.0 \%)$ and germacrene-D-4-ol (8.5\%). Previous chemical investigation of this plant revealed the presence of a-pinene $(2.22 \%)$ along with other compounds. [5] In plant species $T$. linearis oil was dominated by the presence of Thymol $(50.0 \%)$ and germacrene-D-4-ol (6.1\%) whereas reports on T. linearis revealed the presence of thymol, carvacrol, linalool and $p$-cymene. $[10-12,17,20]$ The oil extract of $S$. leucantha have compounds Aromadendrene (20.0\%) and $\beta$ - caryophyllene $(12.0 \%)$ with other compounds in less quantity which is supported by the previous studies in which other compounds were bornyl acetate (40.92\%), azulene $(12.94 \%)$, germacrene-D $(8.26 \%)$, borneol $(8.11 \%)$, bicyclogermacrene $(5.34 \%)$, limonene $(35 \%)$ and a-pinene (17\%) along with the compounds obtained in this study. ${ }^{[14-16,21]}$ The plant species studies A. margaritacea, T. linearis and S. leucantha may have quantitative changes only. Essential oils are volatile in nature the presence of any constituents may depends upon the atmospheric condition and temperature of the collection site of the plant. In view of the cause we have concern mainly with the quantitative variations of the constituents and search for any trace atmospheric conditions.

The extracted oils obtained from the plant species $A$. margaritacea, S. leucantha and T. linearis along with reference antibiotic gentamicin have shown antibacterial activity against bacterial strains of $S$. typhi, E. coli, S. aureus and $P$. aeruginosa with different inhibition zones. The values are listed in Table 2. On comparing inhibition zone values, T. linearis was found to be more effective than $A$. margaritacea and $S$. leucantha against all the bacterial species while the most resistant bacteria $S$. typhi to all the oil extract. The compounds characterized in the oil extract are responsible for the antibacterial activity during the course of investigation recorded. The single compound or the mixture of compounds in the oil extract has shown the resultant antimicrobial effect. A considerable number of compounds have been reported for their biological activity in literature viz. thymol and carvacrol [11], thymol, carvacrol, geraniol [22] and thymol or carvacrol. [23-24] The activity performance of oil extract depends on the compounds present in it are assumed to be bioactive as confirm by the presence in our study. From this brief account, the higher bactericidal activity of $T$. linearis oil than other oils might be due to presence of thymol as major constituents and synergistic effect of various other constituents in the oils.

It has been observed that in the biological screening optimum zone of inhibition for gentamicin is in the range $(18.4-24.3 \mathrm{~mm})$ for all the bacterial strains studied whereas thymol contained essential oil of $T$. linearis has optimum zone of inhibition $(7.0-10.0 \mathrm{~mm})$. Thus, the experimental results further support the biological 
activities of essential oil quantitatively. Due to the increasing demands of herbal medicine in place of synthetic medicine the extracted essential oil is suitable drug in place of gentamicin which is safer in metabolic regulations like kinetic factors involving substrate cofactors and enzymes including alternate or separate pathway for catabolism and anabolism of a key substrate.

The present investigation provides useful information of the compounds present in the extracted oils of the plants. The quantity of the major constituents is different from the quantity reported earlier in same species collected from different sites. It may be concluded in the study the variation in the quantity of different compounds present in extracted oils are influence by atmospheric conditions including soil structure. The essential oil from Anaphalis, Thymus and Salvia species against bacterial strains has antibacterial activity. Thus, the species could be natural agents for fight against bacterial infections and can be a source of antimicrobial drugs.

\section{ACKNOWLEDGEMENTS}

Author's thanks to Department of Microbiology, Sushila Tewari Forest Hospital Trust, Haldwani for antimicrobial activity and Department of Botany, Kumaun University.

\section{REFERENCES}

1. Burt S. Essential oils: Their antimicrobial properties and potential application in foods-A review. Int J Food Microbiol. 2004; 94:223-253.

2. Hussain AI, Anwar F, Chatha SAS, Latif S, Sherazi STH, Ahmad A, Worthington J, Sarker SD. Chemical composition and bioactivity studies of the essential oils from two Thymus species from the Pakistani flora. LWT-Food Sci. Technol. 2013; 50:185-192.

3. Nedorostova L, Kloucek P, Kokoska L, Stolcova M, Pulkrabek J.Antimicrobial properties of selected essential oils in vapour phase against foodborne bacteria. Food Control. 2009; 20:157-160.

4. Anthony JC. Secrets Native American Herbal Remedies. Avery Books, 2001; ISBN, 1-58333-100-X.

5. Ram C, Joshi P, Prasad K. Chemical composition of the essential oil of Anaphalis margaritacea from munsyari, pithoragarh, India. World J Pharm Res. 2017; 6:551-557.

6. Dababneh BF. Antimicrobial activity and genetic diversity of Thymus species on pathogenic microorganisms. J Food Agric Environ. 2007; 5:158-162.

7. Verma RS, Padalia RC, Chanotiya CS, Chauhan A. Chemical investigation of the essential oil of Thymus linearis (Benth. ex Benth) from western Himalaya, India, Nat. Prod Res. 2010; 24:1890-1896.

8. Alexa E, Sumalan RM, Danciu C, Obistioiu D, Negrea M, Poiana MA, Rus C, Radulov I, Pop G, Dehelean C. Synergistic antifungal, allelopatic and anti-proliferative potential of Salvia officinalis L., and Thymus vulgaris L. essential oils. Molecules. 2018; 23:185.
9. Naz A, Saeed M, Ghaffar R, Shirazi M. In vivo biological investgaton of methanolic extract of Thymus linearis whole plant. A J Ethno. 2018; 5:1-5.

10. Rashid MA, Ashraf A, Nazir S, Nazir S, Nadeem R, Iqbal J, Jabbar S, Ahmed A, Tareen RB. Chemical composition and biological (antioxidant, antimicrobial and haemolyitc) activities of essential oils of an endemic plant (Thymus linearis subsp. hedgei Jalas). Rom Biotech Lett. 2017; 22:12560-12567.

11. Mahboubi M, Heidarytabar R, Mahdizadeh E, Hosseini H. Antimicrobial activity and chemical composition of Thymus species and Zataria multiflora essential oils. Agric Nat Resourc. 2017; 51:395-401.

12. Verma RS, Padalia RC, Saikia D, Chauhan A, Krishna V, Sundaresan V, Chemical composition and antimicrobial activity of the essential oils isolated from the herbage and aqueous distillates of two Thymus species. J Essent Oil Bear Pl. 2016; 19:936-943.

13. Haq F, Ahmad H, Alam M. Traditional uses of medicinal plants of N \& iar Khuwarr catchment (District Battagram), Pakistan J Med Plants Res. 2011; 5:39-48.

14. Rondon M, Velasco J, Morales A, Rojas J, Carmona J, Gualtieri M, Hernandez V. Composition and antibacterial activity of the essential oil of Salvia leucantha Cav. cultivated in Venezuela Andes. Rev Latinoam Quím. 2005; 33:55-59.

15. Upadhyaya K, Dixit VK, Padalia RC, Mathela CS. Terpenoid composition and antioxidant activity of essential oil from leaves of Salvia leucantha Cav. J Essent Oil Bear Pl. 2009; 12:551-556.

16. Ali A, Tabanca N, Demirci B, Blythe EK, Ali Z, Baser KH, Khan IA. Chemical composition and biological activity of four Salvia essential oils and individual compounds against two species of mosquitoes. J Agric Food Chem. 2015; 63:44756.

17. Chandra M, Prakash Om, Bachheti R K, Kumar M, Pant AK. Essential oil composition, phenolic constituents, antioxidant and pharmacological activities of Thymus linearis Benth. collected from Uttarakhand region of India. J Essent Oil Bear Pl. 2016; 19:277- 289.

18. Adams RP. Identification of Essential Oil Components by Gas Chromatography/Mass Spectrometry. Allured Publishing Corporation, Carol Stream, IL. 2007.

19. Clinical and Laboratory Standards Institute. Performance Standards for Antimicrobial Disk Susceptibility Tests, 10th Ed. Approved standard. Document M02-A10, CLSI, Wayne, Pa. 2009.

20. Joshi RK. Essential oil composition of Thymus linearis (Benth) from western Himalaya of Uttrakhand, India. Asian J Pharm Tech. 2016; 6:199-201.

21. Tabanca N, Demirci B, Turner JL, Pounders C, Demirci F, Baser KHC, Wedge DE. Microdistillation and analysis of volatiles from eight ornamental Salvia Taxa. Nat Prod Commun. 2010; 5:1421-1426.

22. Van-Den Broucke CO, Lemli JA. Pharmacological and chemical investigation of Thyme liquid extracts. Planta Med. 1981; 41:129-135.

23. Cosentino S, Tuberoso CIG, Pisano B, Satta M, Mascia V, Arzedi E, Palmas F. In-vitro antimicrobial activity and chemical composition of Sardinian thymus essential oils. Lett Appl Microbiol. 1999; 29:130-135.

24. Vardar-Unlu G, Candan F, Sokmen A, Daferera D, Polissiou M, Sokmen M, Donmez E, Tepe B. Antimicrobial and antioxidant activity of the essential oil and methanol extracts of Thymus pectinatus Fisch. et Mey. Var. pectinatus (Lamiaceae). J Agric Food Chem. 2003; 51:63-67. 